\title{
Signaling Components Involved in Leptin-Induced Amplification of the Atherosclerosis-Related Properties of Human Monocytes
}

\author{
Diamantis Konstantinidis $^{a}$ Konstantinos Paletas ${ }^{b}$ George Koliakos ${ }^{c}$ \\ Martha Kaloyianni ${ }^{\mathrm{a}}$ \\ aLaboratory of Animal Physiology, School of Biology, ${ }^{b}$ Laboratory for the Study of Metabolic Diseases, \\ B Medical Clinic, and 'Laboratory of Biological Chemistry, School of Medicine, Aristotle University of Thessaloniki, \\ Thessaloniki, Greece
}

\section{Key Words}

Leptin - Monocytes - Atherosclerosis · Cell adhesion •

Cell migration $\cdot \mathrm{CD} 36 \cdot$ Oxidized low-density lipoproteins ing net which involves the $\mathrm{Na}^{+} / \mathrm{H}^{+}$exchanger isoform-1, the actin cytoskeleton, phosphoinositide 3-kinase, certain conventional isoforms of protein kinase $\mathrm{C}$ and NADPH oxidase.

Copyright $\odot 2008$ S. Karger AG, Basel

\begin{abstract}
Background/Aims: Leptin, a 16-kDa cytokine that is released mainly by the adipose tissue, is known to affect a wide assortment of processes, ranging from energy homeostasis to angiogenesis and the immune response. In the present study, the effect of leptin on atherosclerosis-related properties of human monocytes was investigated. Methods: Monocytes were isolated from whole blood obtained from healthy donors who had normal body mass index values. Pharmacological inhibition of specific signaling proteins was implemented. Fluorescence spectrometry and immunofluorescence techniques, as well as ELISA methods, were utilized. Leptin dose response curves were determined for each type of experiment. Results: Leptin ( $160 \mathrm{ng} / \mathrm{ml}$ ) was found to augment monocyte adhesion to laminin-1 and its migration through this glycoprotein, which is one of the main components of the extracellular matrix. Additionally, leptin increased CD36-receptor surface expression, as well as moderately oxidized low-density lipoprotein $\left(0 x L^{2} L_{3}\right)$ uptake levels. Conclusion: Leptin amplifies the pro-atheromatic properties of human monocytes through a complex signal-
\end{abstract}

\section{Introduction}

Leptin is a $16-\mathrm{kDa}$ adipokine, a cytokine produced by the adipose tissue in response to excessive food intake. It is an anorexigenic hormone, a satiety indicator, that plays a part in regulating energy homeostasis in the body by concurrently lowering appetite and increasing energy expenditure [1]. The primary target of leptin is probably the hypothalamus, where it can affect appetite directly. However, Ob-Rb, the main functional leptin receptor, has been shown to be expressed in a remarkably wide array of cell types, not just in the hypothalamus. Today it is commonly accepted that leptin exerts a pleiotropic effect, partaking in the regulation of such diverse processes as angiogenesis and the immune response $[2,3]$.

Obesity often coincides with hyperleptinemia, the latter being a consequence of the former as obese individuals are often desensitized to leptin. Their leptin resistance is a result of inherited mutations that affect the correct expression of leptin or its receptor [4].

\section{KARGER}

Fax +41613061234 E-Mail karger@karger.ch www.karger.com

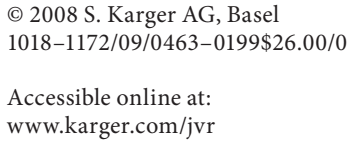

Dr. Martha Kaloyianni

Laboratory of Animal Physiology

Aristotle University of Thessaloniki

GR-54124 Thessaloniki (Greece)

Tel. +30 2310998 271, Fax +30 2310998 269, E-Mail kaloyian@bio.auth.gr 
Human monocytes have been shown to express Ob$\mathrm{Rb}$ and are thus affected by leptin [5]. This is important, considering the fact that monocytes are cells of the immune system that participate in crucial defensive processes such as the inflammatory response, phagocytosis of intruding organisms or particles and the respiratory burst. The latter two phenomena are known to be implicated in the appearance and progression of atherosclerosis and are both mostly associated with macrophages, the cells into which monocytes differentiate [6]. Several studies, in both mice and humans, have demonstrated that leptin can increase the risk of vascular thrombosis [7-9].

Atherosclerosis is one of the main causes of morbidity and mortality in the developed world. It is manifested as gradual arterial stenosis, which over time severely limits blood flow through the artery, thus depriving adjacent tissues of essential nutrients. The consequences of this vary from minor debilitating effects to death, depending on the site of the obstruction and the affected artery [10].

Arterial stenosis is generally observed at arterial locations where lesions have occurred and which constitute potential sites of inflammation. Among the inflammatory events triggered at these areas is the elevated production of chemokines such as monocyte chemotactic protein-1, whose concentration gradients guide leukocytes to the sites of inflammation [11]. Circulating monocytes attracted in this way adhere and migrate into the arterial wall. There they differentiate into macrophages, cells which can phagocytose oxidized low-density lipoproteins (oxLDLs) through scavenger receptors such as CD36. Due to their inability to degrade oxLDLs, macrophages accumulate oxLDLs, finally becoming foam cells, the fundamental ingredients of atheromatous plaques, which are principally responsible for arterial stenosis $[12$, 13].

It has been noted in monocytes that the leptin and insulin pathways overlap at certain points [14]; however, the mode of leptin action and the signaling pathways that are utilized, particularly in relation to atherosclerosis, have not yet been fully elucidated. The present study focuses on the investigation of the effects of leptin signaling in human monocytes in relation to certain atherosclerotic properties, namely monocyte adhesion to and migration through the extracellular matrix component laminin-1, CD36 scavenger receptor expression and oxLDL uptake. Pharmacological inhibition of selected proteins known for their involvement in major signaling pathways was implemented in order to deduce their effects on leptin signaling in relation to the aforementioned properties.

\section{Materials and Methods}

\section{Materials}

Recombinant human leptin was sourced from R\&D Systems (Minneapolis, Minn., USA). Ficoll-Paque Plus (1.077 g/ml) and Percoll $(1.130 \mathrm{~g} / \mathrm{ml})$ were from Amersham Biosciences (Piscataway, N.J., USA). Anti-human CD14 R-phycoerythrin conjugated antibody, hexadecyltrimethylammonium bromide and dianisidine dihydrochloride tablets, diphenyleneiodonium chloride (DPI) and $\mathrm{N}_{\omega}$-nitro-L-arginine methyl ester hydrochloride (L-NAME) were from Sigma (St. Louis, Mo., USA). Low-density lipoprotein (LDL) and bovine serum albumin were from AppliChem (Darmstadt, Germany). Anti-human CD36 FITC-conjugated antibody was from Serotec (Kidlington, UK). DiI $\left(1,1^{\prime}\right.$ dioctadecyl-3,3,3',3'-tetramethyl-indocarbocyanine perchlorate) was from Invitrogen (Carlsbad, Calif., USA). Cariporide was from Sanofi-Aventis (Paris, France). Iscove's Modified Dulbecco's Medium (IMDM), fetal calf serum (FCS), penicillin/streptomycin, and L-glutamine were from Biochrom (Berlin, Germany). Cytochalasin D and wortmannin were from Fluka (Buchs, Switzerland). GF109203X and Gö6976 were from Alexis (Lausen, Switzerland). All other reagents were of analytical grades and were obtained from commercial sources.

\section{Leptin and Inhibitors}

The leptin concentration used was $160 \mathrm{ng} / \mathrm{ml}(10 \mathrm{nM})$, which is within the range used in other studies on leptin and which can be observed in patients suffering from hyperleptinemia, a direct result of severe obesity and its associated leptin resistance $[5,15]$. Moreover, dose dependence measurements for each of our experiments showed that this concentration was more than adequate to permit the manifestation of the monocyte atherosclerosis-related properties we studied. Cariporide $(20 \mathrm{nM})$ inhibits the $\mathrm{Na}^{+} / \mathrm{H}^{+}$ exchanger isoform-1 (NHE1). Cytochalasin D $(2 \mu \mathrm{M})$ disrupts actin polymerization. Wortmannin $(50 \mathrm{nM})$ inhibits phosphoinositide 3-kinase (PI3K). GF109203X (10 $\mu \mathrm{M})$ inhibits all protein kinase C (CPKC) isoforms. Gö6976 (500 nM) inhibits $\alpha$ and $\beta$ isoforms of PKC $\left(\mathrm{PKC}_{\alpha}, \mathrm{PKC}_{\beta \mathrm{I}}\right.$ and $\left.\mathrm{PKC}_{\beta I I}\right)$. DPI $(10 \mu \mathrm{M})$ inhibits NADPH oxidase and nitric oxide synthase. L-NAME $(100 \mu \mathrm{M})$ inhibits solely nitric oxide synthase.

\section{Monocyte Isolation}

Monocytes were isolated from heparinized whole blood from healthy individuals, as described previously [16]. Informed consent was given by all blood donors. In brief, heparinized whole blood was diluted with phosphate buffered saline (PBS) $1 \times(1 \mathrm{mM}$ EDTA, pH 7.2) and underlayered with the use of an 18-gauge spinal needle with Ficoll-Paque Plus $(1.077 \mathrm{~g} / \mathrm{ml})$ in $50-\mathrm{ml}$ falcon tubes. After centrifugation ( $400 \mathrm{~g}$ for $20 \mathrm{~min}$, room temperature, no brake) the peripheral blood mononuclear cell (PBMC) layer was collected and put in new, clean 50-ml Falcon tubes. The PBMCs were washed 3 times with PBS $1 \times(1 \mathrm{mM}$ EDTA, pH 7.2). They were then diluted with complete IMDM and overlayered on $46 \%$ Percoll in 50-ml Falcon tubes. After centrifugation (550 $\mathrm{g}$ for $30 \mathrm{~min}$, room temperature, no brake) the monocyte layer was collected, diluted with PBS $1 \times(1 \mathrm{~mm}$ EDTA, $\mathrm{pH}$ 7.2) and washed twice with PBS $1 \times$ before being used in the experiments. Monocyte purity in the final samples was measured on a Beckman Coulter EPICS XL-MCL flow cytometer using the CD14 antibody and was found to be $>85 \%$. 


\section{Monocyte Adhesion Assay}

Laminin-1 was diluted in PBS $1 \times(\mathrm{pH} 7.2)$ to a final concentration of $37.5 \mu \mathrm{g} / \mathrm{ml} .50-\mu \mathrm{l}$ aliquots of the solution were placed in each of the wells on a 96-well polystyrene plate, and left uncovered to dry overnight at room temperature. $100 \mu \mathrm{l}$ of monocytes $\left(10^{6} / \mathrm{ml}\right)$ in complete IMDM were added to each well. Additionally, 2-4 Eppendorf tubes were also filled with $10^{5}$ cells to be used later as $100 \%$ myeloperoxidase (MPO) controls. The cells were then incubated with the appropriate inhibitors for $15 \mathrm{~min}$ at $37^{\circ} \mathrm{C}$, followed by incubation with leptin for $30 \mathrm{~min}$ at $37^{\circ} \mathrm{C}$. Non-adhered cells were removed by washing the plates with $\mathrm{PBS} 1 \times(\mathrm{pH}$ 7.0) and monocyte binding was quantified using the myeloperoxidase assay as previously described [17]. In brief, the cells were lysed using $0.5 \%(\mathrm{w} / \mathrm{v})$ hexadecyltrimethylammonium bromide in PBS ( $\mathrm{pH}$ 6.0) for $30 \mathrm{~min}$ at $37^{\circ} \mathrm{C}$. After lysis, $50 \mu \mathrm{lof} 0.2 \mathrm{mg} / \mathrm{ml}$ dianisidinedihydrochloride in PBS ( $\mathrm{pH} 6.0$ ) containing $0.4 \mathrm{mM}$ $\mathrm{H}_{2} \mathrm{O}_{2}$ were added to each well. After $15 \mathrm{~min}$, the MPO activity of the lysate was measured spectrophotometrically at $405 \mathrm{~nm}$, using an ELISA reader. The Eppendorf tubes were centrifuged, the supernatant was removed, and the sedimented cells were lysed, transferred to clean wells and myeloperoxidase activity was measured as described above. The number of bound cells was estimated by comparing the optical density of the test wells with the optical density of the reference wells.

\section{Monocyte Migration Assay}

Transmigration of monocytes through laminin-1-coated filters was performed as previously described [18]. In brief, filters of $6.5 \mathrm{~mm}$ diameter, 5 - $\mu \mathrm{m}$ pore Transwell culture inserts (Costar, Cambridge, Mass., USA) were coated with $20-\mu \mathrm{g} / \mathrm{ml}$ laminin-1 and left to dry overnight at $4^{\circ} \mathrm{C}$. Non-adhered molecules were removed, and the filters were then blocked with $150 \mu \mathrm{l}$ of $0.5 \%$ bovine serum albumin by incubation for $1 \mathrm{~h}$ at $37^{\circ} \mathrm{C}$. Monocytes $(5$ $\times 10^{5}$ cells/insert) were incubated in $250 \mu \mathrm{l}$ of complete IMDM without FCS and the appropriate inhibitors were then added to the top chamber of the insert while $500 \mu \mathrm{l}$ of IMDM containing $10 \%$ FCS was added to the lower chamber. The plates were incubated for $15 \mathrm{~min}$ at $37^{\circ} \mathrm{C}$ followed by incubation with leptin for 30 $\min$ at $37^{\circ} \mathrm{C}$. After incubation, non-migrated cells were removed very carefully through the use of cotton tips immersed in PBS $1 \times$ ( $\mathrm{pH}$ 7.0). The cells on the filters were fixed and stained with a Hemacolor staining kit (Merck) and left to dry for $10 \mathrm{~min}$ at room temperature. The complete IMDM was then removed from the lower chambers and $200 \mu \mathrm{l}$ of $10 \%$ acetic acid was added to each one in order to remove the bound dye. After gentle shaking for 3-4 min, the contents of the lower chambers were transferred to wells on a 96-well plate and measured, as previously described, at $590 \mathrm{~nm}$ in an ELISA reader [19].

\section{CD36 Receptor Measurement}

Monocytes were incubated with the appropriate inhibitors for $15 \mathrm{~min}$ at $37^{\circ} \mathrm{C}$, which was followed by incubation with leptin for $30 \mathrm{~min}$ at $37^{\circ} \mathrm{C}$. The controls were incubated in parallel at $37^{\circ} \mathrm{C}$. The CD36 receptor FITC-conjugated antibody was added to all samples, which was followed by incubation for $10 \mathrm{~min}$ at $37^{\circ} \mathrm{C}$. Monocytes were then washed 3 times with PBS $1 \times(\mathrm{pH} 7.0)$ and fluorescence was measured under continuous magnetic stirring at $20^{\circ} \mathrm{C}$ in a $3-\mathrm{ml}$ quartz cuvette using a Shimadzu fluorescence thermostatic spectrophotometer, with the excitation and emission wavelengths set at 495 and $525 \mathrm{~nm}$, respectively.

\section{oxLDL Uptake}

Preparation of Dil-oxLDLs. LDLs were oxidized and then labeled with DiI towards DiI-oxLDL as previously described [20, 21]. In order to produce oxLDL 3 , LDLs $(0.2 \mathrm{mg} / \mathrm{ml})$ were incubated with $5 \mu \mathrm{M} \mathrm{CuSO}_{4}$ in $\mathrm{PBS} 1 \times$ for $3 \mathrm{~h}$ at $37^{\circ} \mathrm{C}$. Similarly, LDLs $(2 \mathrm{mg} / \mathrm{ml})$ were incubated with $50 \mu \mathrm{M} \mathrm{CuSO}_{4}$ in $\mathrm{PBS} 1 \times$ for $24 \mathrm{~h}$ at $37^{\circ} \mathrm{C}$ in order to produce oxLDL 24 . Both reactions were terminated with the addition of EDTA to a final concentration of 0.25 $\mathrm{mM}$. Both types of oxLDLs were then incubated with DiI for $18 \mathrm{~h}$ at $37^{\circ} \mathrm{C}$, at a ratio of $300 \mu \mathrm{g}$ of DiI to $1 \mathrm{mg}$ of oxLDLs. This was followed by ultracentrifugation at $39,000 \mathrm{rpm}$ for $24 \mathrm{~h}$ at room temperature using a fixed angle rotor (Ti 50) and dialysis against PBS $1 \times$. Finally, oxLDLs were sterilized by passing them through a $0.45-\mu \mathrm{m}$ filter. The final concentrations of the obtained DiIoxLDLs were quantified by the Bradford method.

Experimental Procedure. Monocytes were incubated with the appropriate inhibitors in FCS-deficient complete IMDM medium for $15 \mathrm{~min}$ at $37^{\circ} \mathrm{C}$. Leptin was then added with DiI-oxLDL (100 $\mathrm{ng} / \mathrm{ml}$ ) and monocytes were incubated at $37^{\circ} \mathrm{C}$ for the desired time. After this, monocytes were washed 3 times with PBS $1 \times$ ( $\mathrm{pH}$ 7.0) and oxLDL phagocytosis was quantified by the measurement of fluorescence under continuous magnetic stirring at $20^{\circ} \mathrm{C}$ in a $3-\mathrm{ml}$ quartz cuvette using a Shimadzu fluorescence thermostatic spectrophotometer, with the excitation and emission wavelengths set at 520 and $578 \mathrm{~nm}$, respectively.

\section{Statistical Analysis}

Values are expressed as arithmetic means \pm standard deviations (SDs). Comparison between groups was conducted using the 2-tailed paired t test and the 1-way analysis of variance with the Student-Newman-Keuls test. $\mathrm{p}<0.05$ was used as the minimum accepted significance level. For statistical evaluation, the statistical software GraphPad InStat version 3.00 was used (GraphPad Software, San Diego, Calif., USA).

\section{Results}

\section{Dose-Dependent Effect of Leptin}

The leptin concentration we used (160 ng/ml) appeared capable of delivering an approximate peak effect for all the monocyte atherosclerosis-related properties we studied (fig. 1).

\section{Adhesion to Laminin-1}

The incubation of monocytes with $160-\mathrm{ng} / \mathrm{ml}$ leptin resulted in a 1.89 -fold increase $(\mathrm{p}<0.05)$ in adhesion to laminin-1 compared to the control population (fig. 2). The leptin sample value, in particular, corresponded to $78.2 \%$ of the MPO $100 \%$ (myeloperoxidase $100 \%$, the expected value if all the cells had adhered to laminin-1) compared to just $41.5 \%$ for the control sample. All the inhibitors used, apart from L-NAME, attenuated this effect of leptin. 

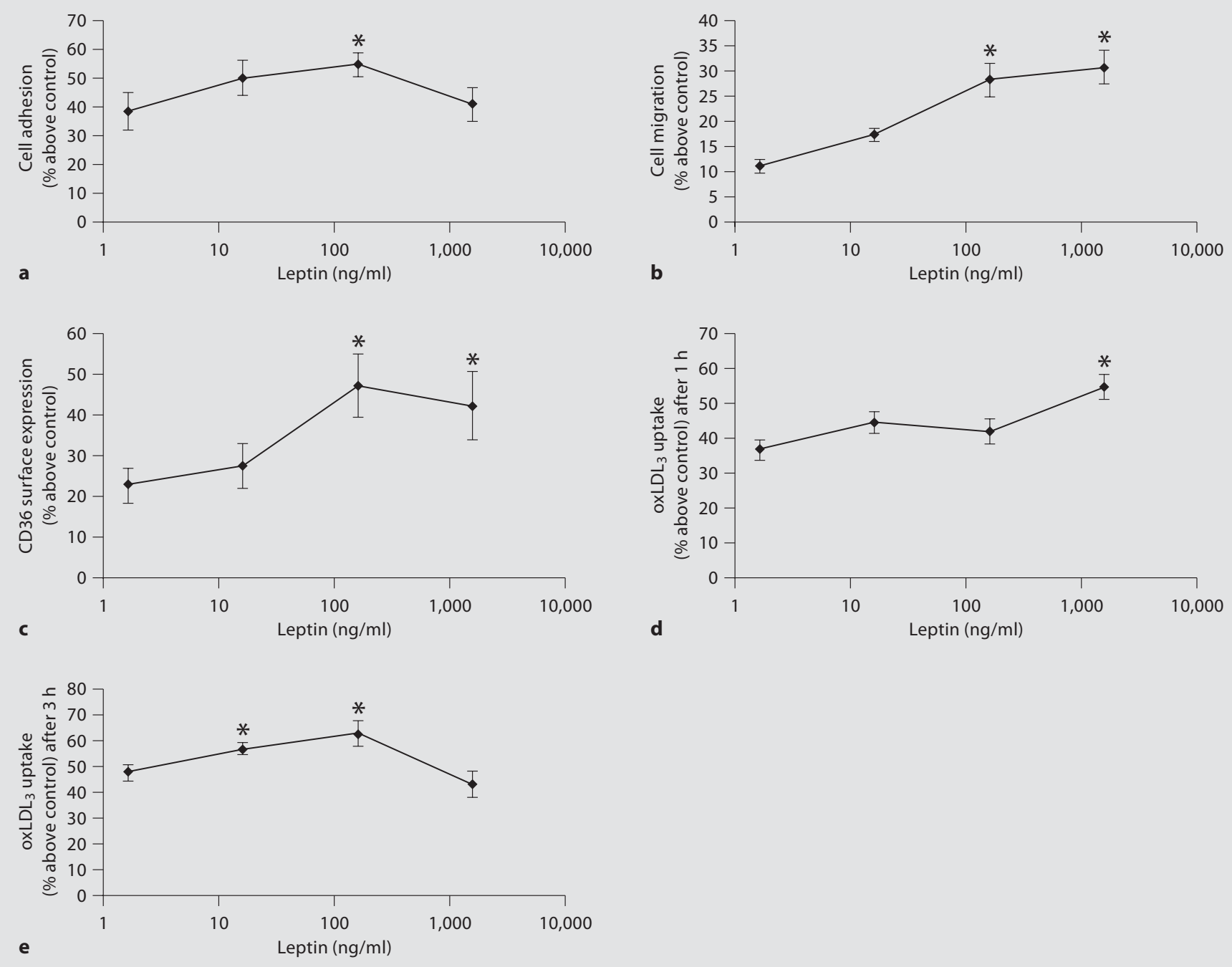

Fig. 1. Dose-dependent effects of leptin. Monocytes were incubated at $37^{\circ} \mathrm{C}$ with 4 different concentrations of leptin $(1.6,16,160$ and 1,600 $\mathrm{ng} / \mathrm{ml}$ ) for $30 \mathrm{~min}(\mathbf{a}-\mathbf{c}), 1 \mathrm{~h}(\mathbf{d})$ or $3 \mathrm{~h}(\mathbf{e})$. Each graph shows the mean percentage increase, compared to controls, of at least 6 experiments. The error bars indicate SD. The level of significance of the differences between the samples was calculated by ANOVA with a Student-Newman-Keuls post-test. The increase caused by leptin was statistically significant $(\mathrm{p}<0.05)$ compared to the control sample in all cases and at all leptin concentrations

used. a Dose-dependent effect of leptin on cell adhesion. ${ }^{*} \mathrm{p}<$ 0.05 versus leptin $1.6 \mathrm{ng} / \mathrm{ml}$. b Dose-dependent effect of leptin on cell migration. ${ }^{*} \mathrm{p}<0.05$ versus leptin 1.6 and $16 \mathrm{ng} / \mathrm{ml}$. c Dosedependent effect of leptin on CD36 receptor surface expression. ${ }^{*} \mathrm{p}<0.05$ versus leptin 1.6 and $16 \mathrm{ng} / \mathrm{ml}$. d Dose-dependent effect of leptin on oxLDL 3 uptake after $1 \mathrm{~h}$ of incubation. ${ }^{*} \mathrm{p}<0.05$ versus leptin 1.6, 16 and $160 \mathrm{ng} / \mathrm{ml}$. e Dose-dependent effect of leptin on oxLDL 3 uptake after $3 \mathrm{~h}$ of incubation. ${ }^{*} \mathrm{p}<0.05$ versus leptin 1.6 and $1,600 \mathrm{ng} / \mathrm{ml}$.

\section{Migration through Laminin-1}

Incubation of monocytes with $160-\mathrm{ng} / \mathrm{ml} \mathrm{leptin} \mathrm{result-}$ ed in a 1.39 -fold increase $(\mathrm{p}<0.05)$ in migration through laminin-1 (fig. 3). The results obtained after incubation with the inhibitors indicate the involvement of NHE1, the actin cytoskeleton, PI3K and one or more of the $\alpha, \beta_{\mathrm{I}}$ and $\beta_{\mathrm{II}}$ isoforms of PKC in this leptin-induced mechanism.

\section{CD36 Receptor Expression Measurement}

Incubation of monocytes with $160-\mathrm{ng} / \mathrm{ml}$ leptin resulted in a 1.5 -fold increase $(\mathrm{p}<0.05)$ in CD36 receptor surface expression compared to the control monocyte population (fig. 4). Subsequent incubation with the available inhibitors indicated the involvement of NHE1, PI3K, NADPH oxidase and one or more of the $\alpha, \beta_{\text {I }}$ and $\beta_{\text {II }}$ iso- 


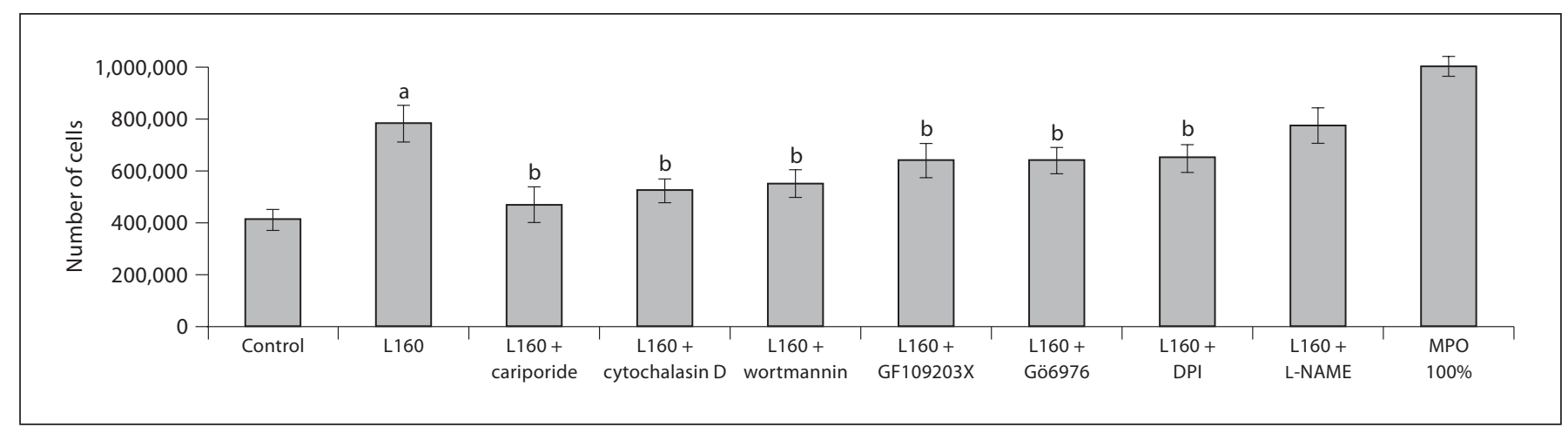

Fig. 2. Adhesion to laminin-1. Monocytes were pre-incubated for $15 \mathrm{~min}$ at $37^{\circ} \mathrm{C}$ with the inhibitors, leptin ( 160 $\mathrm{ng} / \mathrm{ml}$ ) was then added and the sample was incubated for a further $30 \mathrm{~min}$ at $37^{\circ} \mathrm{C}$. The arithmetic means of at least 6 experiments are shown. Error bars indicate SD. The level of significance of the differences between the samples was calculated by ANOVA with a Student-Newman-Keuls post-test. ${ }^{a} \mathrm{p}<0.05$ versus control. ${ }^{\mathrm{b}} \mathrm{p}<0.05$ versus leptin. See Methods for inhibitor concentrations.

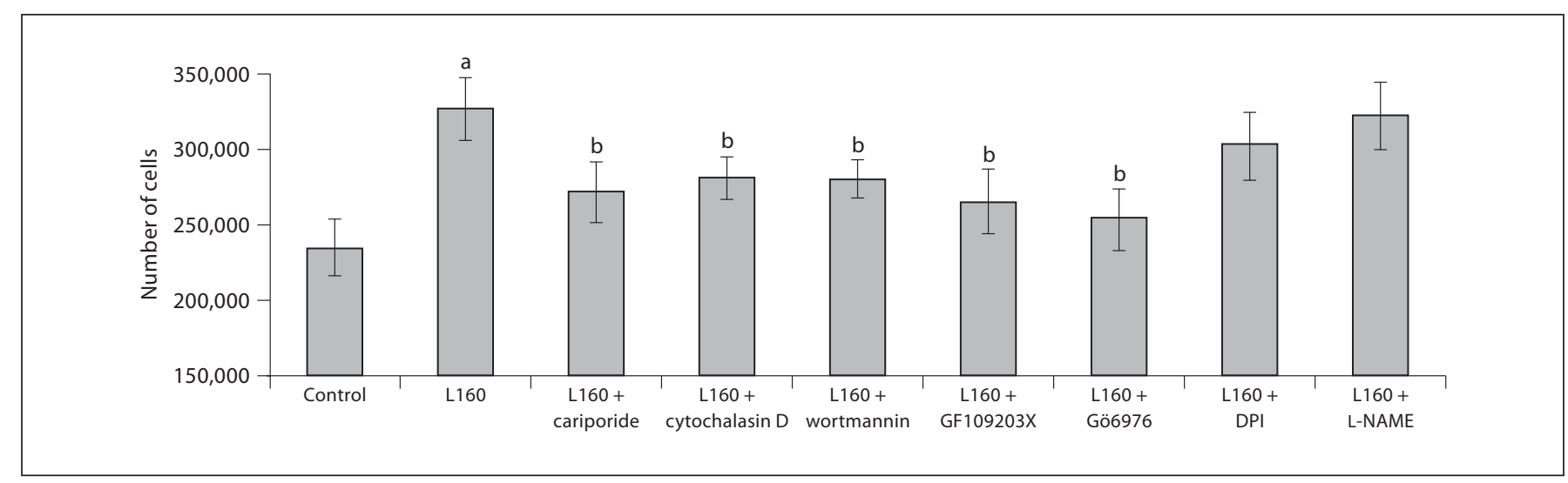

Fig. 3. Migration through laminin-1. Monocytes were pre-incubated for $15 \mathrm{~min}$ at $37^{\circ} \mathrm{C}$ with the inhibitors, leptin $(160 \mathrm{ng} / \mathrm{ml})$ was then added and the sample was incubated for a further $30 \mathrm{~min}$ at $37^{\circ} \mathrm{C}$. The arithmetic means of at least 6 experiments are shown. Error bars indicate SD. The level of significance of the differences between the samples was calculated by ANOVA with a Student-Newman-Keuls post-test. ${ }^{a} \mathrm{p}<0.05$ versus control. ${ }^{\mathrm{b}} \mathrm{p}<0.05$ versus leptin. See Methods for inhibitor concentrations.

forms of PKC in the leptin-mediated CD36 receptor surface expression.

\section{oxLDL $L_{3}$ Uptake}

Incubation of monocytes with $160-\mathrm{ng} / \mathrm{ml}$ leptin resulted in 1.54-fold and 1.64-fold increases (both $\mathrm{p}<0.05$ ) in oxLDL 3 uptake after 1 and $3 \mathrm{~h}$, respectively, compared to the control population (fig. 5). Interestingly, incubation with $160-\mathrm{ng} / \mathrm{ml}$ leptin for $5 \mathrm{~h}$ did not result in a statistically significant increase in $\mathrm{oxLDL}_{3}$ uptake. The addition of cariporide or wortmannin attenuated the effect of leptin after both 1 and $3 \mathrm{~h}$ (particularly after $1 \mathrm{~h}$ ), thus indicating the involvement of NHE1 and PI3K. Additionally, NADPH oxidase appears to have a role, as its inhibition also attenuates leptin-mediated oxLDL $_{3}$ uptake after 1 and $3 \mathrm{~h}$.

\section{Effect of Inhibitors on Control Samples}

We measured the effect of the inhibitors on the processes studied (cell adhesion, cell migration, CD36 surface expression and oxLDL 3 uptake), as well as on cell viability in the absence of leptin. At the concentrations 


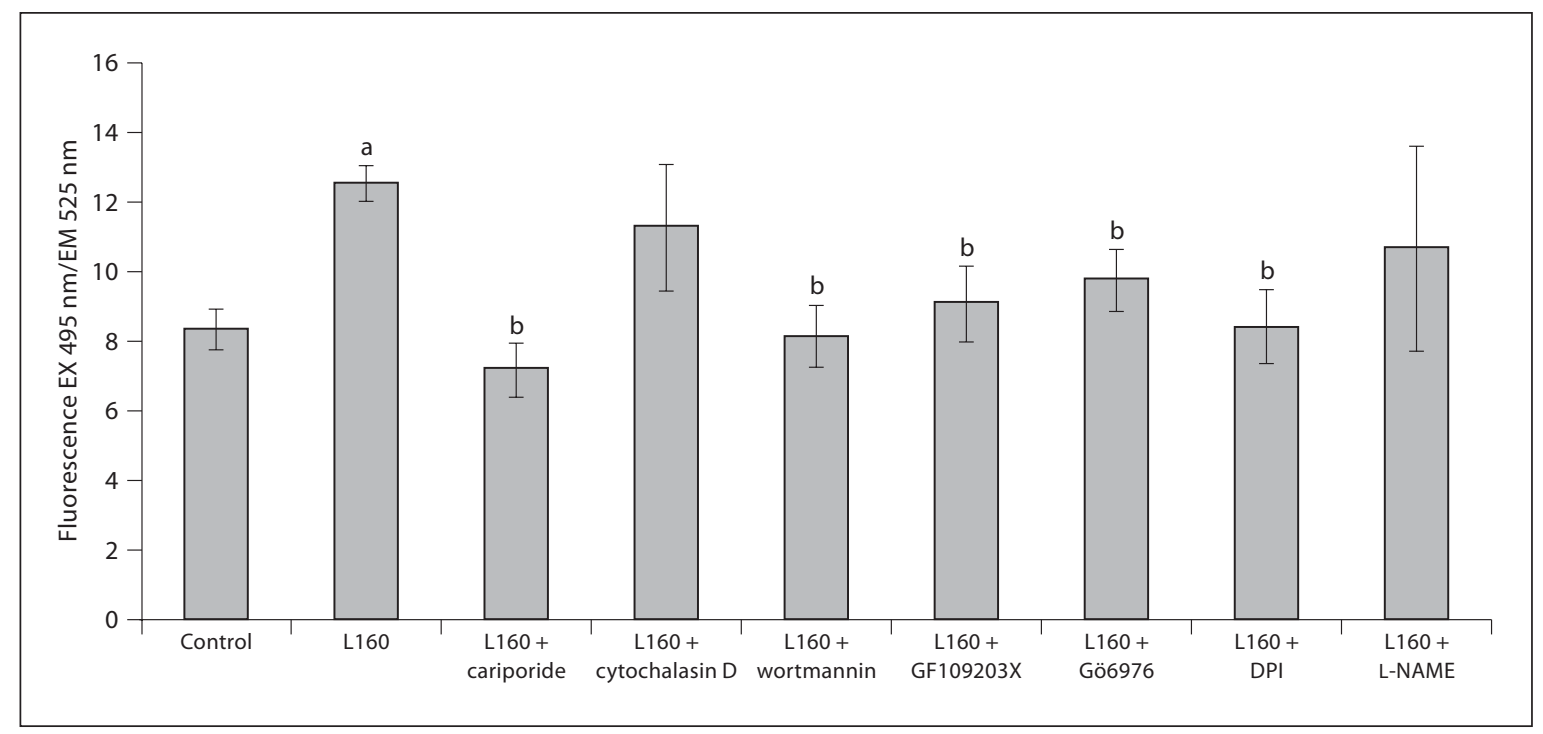

Fig. 4. CD36 receptor surface expression. Monocytes were pre-incubated for $15 \mathrm{~min}$ at $37^{\circ} \mathrm{C}$ with the inhibitors, leptin $(160 \mathrm{ng} / \mathrm{ml})$ was then added and the sample was incubated for a further $30 \mathrm{~min}$ at $37^{\circ} \mathrm{C}$. The arithmetic means of at least 6 experiments are shown. Error bars indicate SD. The level of significance of the differences between the samples was calculated by ANOVA and Student-Newman-Keuls post-test. ${ }^{\mathrm{a}} \mathrm{p}<0.05$ versus control. ${ }^{\mathrm{b}} \mathrm{p}<0.05$ versus leptin. See Methods for inhibitor concentrations.

we used, the inhibitors in the absence of leptin did not affect in a statistically significant way either the processes we studied (table 1) or cell viability (data not shown).

\section{Discussion}

During early atherogenic events, monocytes pass through the arterial walls into areas where lesions exist. Once there, monocy tes can cause damage to the endothelium by excessively producing reactive oxygen species, thus creating new lesions or enlarging pre-existing ones. The resulting inflammation leads to the formation of atheromatous plaques, of which leukocytes and monocytes in particular, in the form of foam cells, are fundamental components [22]. Adhesion to and migration through laminin-1 serve as good representations of the elemental procedures that must occur for monocytes to reach the area of inflammation. After chemotactic recruitment to the area where a lesion exists, monocytes adhere to endothelial cells of the vascular intima through interactions with components of the extracellular matrix, such as laminin-1. From our results, it is apparent that the ability of monocytes to adhere to laminin-1 is significantly augmented by leptin. Our results also indicate that the mechanism of leptin-induced monocyte adhesion to laminin-1 involves a large number of intracellular components, two of which are NHE1 and the actin cytoskeleton. NHE1 is known to be linked to the cytoskeleton, through which it participates in signal transduction [23]. Additionally, our results point to roles for $\mathrm{PI} 3 \mathrm{~K}$, certain conventional $\mathrm{PKCs}$ (the $\alpha, \beta_{\text {I }}$ and $\beta_{\text {II }}$ isoforms) and NADPH oxidase in the regulation of leptin-induced monocyte laminin adhesion.

After interaction between monocytes and the extracellular matrix has been established, the monocytes migrate to the lesion area through a particularly complex procedure, guided by chemotactic stimuli produced by chemokines such as monocyte chemotactic protein-1 [24]. This procedure involves interactions between cell adhesion molecules on the surface of monocytes (mainly selectins and integrins) and their ligands on endothelial cells, as well as components of the extracellular matrix. Moreover, a previous study has shown that leptin can activate microvascular endothelial cells, thus promoting monocyte diapedesis and their differentiation into tissue-resident macrophages [25]. We found that leptin had a significant positive effect on monocyte migration through laminin-1. This effect is possibly mediated through an increased surface expression of the appropriate integrins, since interaction between integrin and laminin-1 in monocytes and other cells has been previously 


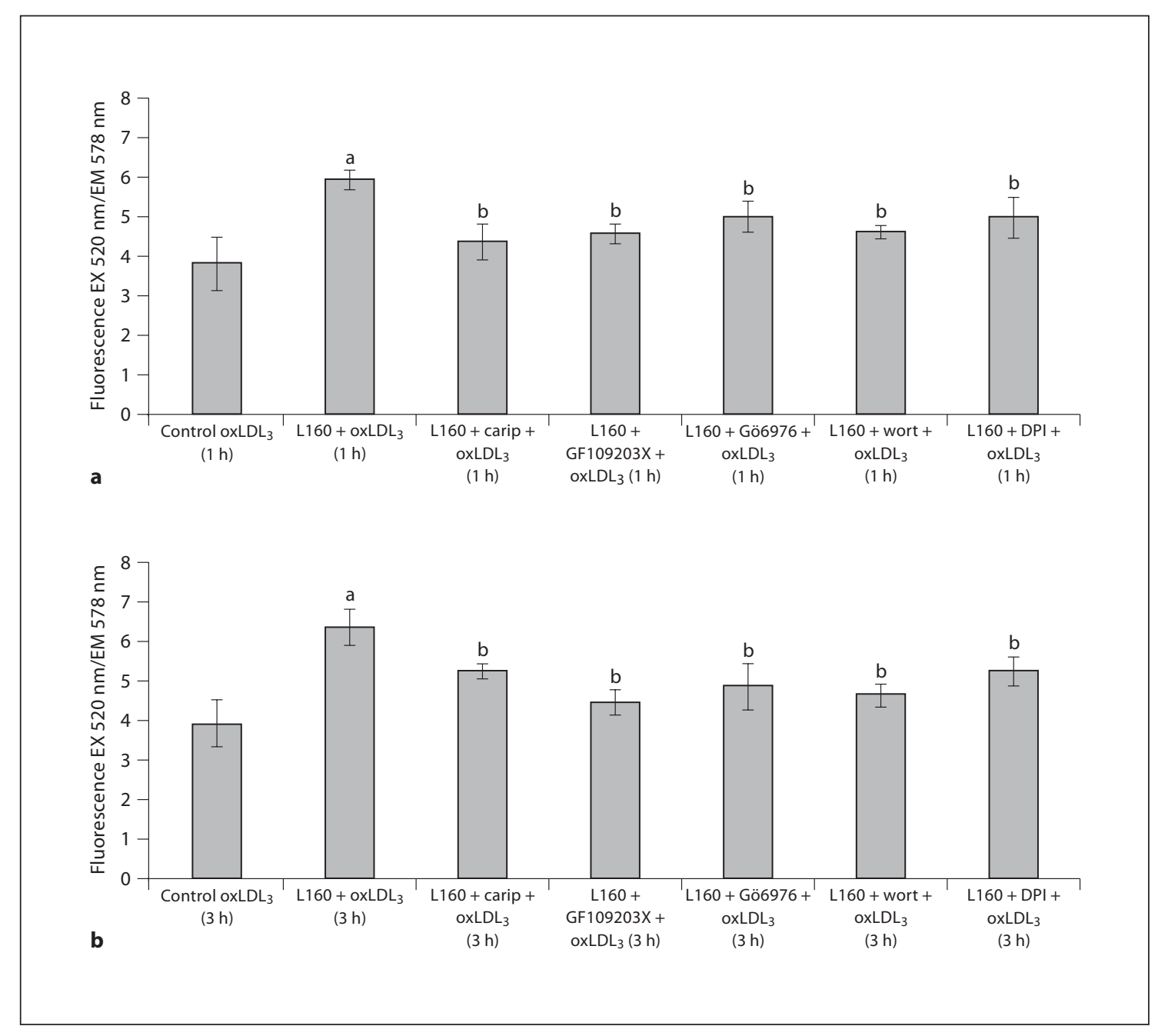

Fig. 5. Uptake of oxLDL 3 after $1 \mathrm{~h} \mathrm{(a)} \mathrm{or} 3 \mathrm{~h} \mathrm{(b)} \mathrm{of} \mathrm{incubation} \mathrm{with} \mathrm{leptin.} \mathrm{Monocytes} \mathrm{were} \mathrm{pre-incubated} \mathrm{for} 15$ min at $37^{\circ} \mathrm{C}$ with cariporide, wortmannin, GF109203X, Gö6976 or DPI, then leptin (160 ng/ml) was added and the sample was incubated for a further 1,3 or $5 \mathrm{~h}$ at $37^{\circ} \mathrm{C}$ (results for $5 \mathrm{~h}$ not shown). The arithmetic means of at least 6 experiments are shown. Error bars indicate SD. The level of significance of the differences between the samples was calculated by ANOVA with a Student-Newman-Keuls post-test. ${ }^{a} \mathrm{p}<0.05$ versus the respective control. ${ }^{b} \mathrm{p}<0.05$ versus the respective leptin sample. See Methods for inhibitor concentrations.

reported [26, 27]. Our pharmacological inhibition results imply that NHE1, the actin cytoskeleton, PI3K and the $\alpha$ and/or $\beta_{\mathrm{I}}$ and $\beta_{\mathrm{II}}$ isoforms of PKC take part in this leptininduced mechanism. The activation of NHE1 and the polymerization of actin that are required during cellular adhesion and migration are tightly regulated by a mechanism that involves certain GTPases, such as RhoA [28, 29]. Another GTPase, Rac, is thought to be involved in a positive feedback loop with PI3K that results in the promotion of cellular migration $[28,30]$, something which is in accordance with our findings.

Leptin Amplifies Atherosclerosis-Related Properties of Monocytes
Because of the high concentrations of reactive oxygen species in and around areas of inflammation, LDLs become oxidized (oxLDLs). In particular, reactive oxygen species released by the NADPH oxidase of endothelial cells, smooth muscle cells and, possibly, monocytes which reside in the area, are thought to play a crucial role in this oxidation process [31]. Moreover, nitric oxide (NO) produced by the NO synthase of the surrounding cells can interact with molecular oxygen and superoxide radicals to produce reactive nitrogen species which also have the capacity to oxidize LDLs to oxLDLs $[32,33]$. Monocytes 
Table 1. Effect of inhibitors on 'resting' monocyte adhesion to laminin-1, monocyte migration through laminin-1, CD36-receptor surface expression and oxLDL 3 uptake after 1 and $3 \mathrm{~h}$ of incubation

\begin{tabular}{|c|c|c|c|c|c|c|c|c|c|}
\hline Units & Control & L160 & Cariporide & $\begin{array}{l}\text { Cytochalasin } \\
\text { D }\end{array}$ & $\begin{array}{l}\text { Wort- } \\
\text { mannin }\end{array}$ & GF109203X & Gö6976 & DPI & L-NAME \\
\hline $\begin{array}{l}\text { Cell adhesion } \\
\text { Number of adhered cells }\end{array}$ & $\begin{array}{l}414,603 \pm 42,079 \\
\text { MPO } 100 \% \text { control: } \\
1,000,000 \pm 39,604\end{array}$ & $\begin{array}{l}782,178 \pm \\
71,782^{*}\end{array}$ & $\begin{array}{l}424,504 \pm \\
42,079\end{array}$ & $\begin{array}{l}389,851 \pm \\
34,664\end{array}$ & $\begin{array}{l}399,752 \pm \\
47,044\end{array}$ & $\begin{array}{l}415,840 \pm \\
35,902\end{array}$ & $\begin{array}{l}384,900 \pm \\
38,378\end{array}$ & $\begin{array}{l}379,950 \pm \\
37,140\end{array}$ & $\begin{array}{l}420,791 \pm \\
56,948\end{array}$ \\
\hline $\begin{array}{l}\text { Cell migration } \\
\text { Number of migrated cells }\end{array}$ & $\begin{array}{l}235,280 \pm \\
17,939\end{array}$ & $\begin{array}{l}327,080 \pm \\
20,567^{*}\end{array}$ & $\begin{array}{l}250,044 \pm \\
17,416\end{array}$ & $\begin{array}{l}247,556 \pm \\
28,612\end{array}$ & $\begin{array}{l}248,178 \pm \\
24,880\end{array}$ & $\begin{array}{l}242,580 \pm \\
13,062\end{array}$ & $\begin{array}{l}241,958 \pm \\
26,124\end{array}$ & $\begin{array}{l}248,800 \pm \\
19,282\end{array}$ & $\begin{array}{l}250,044 \pm \\
28,612\end{array}$ \\
\hline $\begin{array}{l}\text { CD36 receptor surface expressic } \\
\text { Fluorescence EX } 495 \mathrm{~nm} / \\
\text { EM } 525 \mathrm{~nm}\end{array}$ & $\begin{array}{l}8.379 \pm \\
0.579\end{array}$ & $\begin{array}{l}12.554 \pm \\
0.515^{*}\end{array}$ & $\begin{array}{l}7.987 \pm \\
0.434\end{array}$ & $\begin{array}{l}8.432 \pm \\
0.232\end{array}$ & $\begin{array}{l}7.775 \pm \\
0.412\end{array}$ & $\begin{array}{l}7.950 \pm \\
0.356\end{array}$ & $\begin{array}{l}8.145 \pm \\
0.244\end{array}$ & $\begin{array}{l}8.274 \pm \\
0.732\end{array}$ & $\begin{array}{l}8.310 \pm \\
0.463\end{array}$ \\
\hline $\begin{array}{l}\text { oxLDL }_{3} \text { uptake after } 1 \mathrm{~h} \\
\text { Fluorescence EX } 520 \mathrm{~nm} / \\
\text { EM } 578 \mathrm{~nm}\end{array}$ & $\begin{array}{l}4.110 \pm \\
0.635\end{array}$ & $\begin{array}{l}6.047 \pm \\
0.243^{*}\end{array}$ & $\begin{array}{l}4.012 \pm \\
0.437\end{array}$ & - & $\begin{array}{l}4.006 \pm \\
0.543\end{array}$ & $\begin{array}{l}3.832 \pm \\
0.322\end{array}$ & $\begin{array}{l}4.130 \pm \\
0.564\end{array}$ & $\begin{array}{l}4.043 \pm \\
0.232\end{array}$ & - \\
\hline $\begin{array}{l}\text { oxLDL }_{3} \text { uptake after } 3 \mathrm{~h} \\
\text { Fluorescence EX } 520 \mathrm{~nm} / \\
\text { EM } 578 \mathrm{~nm}\end{array}$ & $\begin{array}{l}3.882 \pm \\
0.643\end{array}$ & $\begin{array}{l}6.414 \pm \\
0.435^{*}\end{array}$ & $\begin{array}{l}3.994 \pm \\
0.342\end{array}$ & - & $\begin{array}{l}3.876 \pm \\
0.343\end{array}$ & $\begin{array}{l}3.622 \pm \\
0.389\end{array}$ & $\begin{array}{l}3.940 \pm \\
0.298\end{array}$ & $\begin{array}{l}3.922 \pm \\
0.440\end{array}$ & - \\
\hline
\end{tabular}

and macrophages phagocytose oxLDLs and become foam cells. They grow in size as they cannot metabolize or dispose of oxLDLs, which eventually results in cell death that further fuels the pro-atherosclerotic inflammatory process [22]. The internalization of oxLDLs is mediated primarily by $\mathrm{CD} 36$, a scavenger receptor known to be expressed by monocytes and macrophages [34, 35]. A consensus has not yet been reached as to whether CD36 function is pro-atherogenic or protective against atherosclerosis. From one perspective, $\mathrm{CD} 36$ has a valuable role by removing toxic oxLDLs from the inflammation area. This removal of oxLDLs, however, is what leads monocytes and macrophages to become foam cells [36]. In our experiments, leptin was found to up-regulate the surface expression of CD36 receptor in human monocytes. These findings are in agreement with a recent study involving cardiomyocytes [37]. Specific pharmacological inhibition showed that NHE1, PI3K, $\alpha$ and/or $\beta_{\text {I }}$ and $\beta_{\text {II }}$ PKC isoforms and NADPH oxidase take part in this leptin-induced signaling mechanism.

Based on these findings, we investigated directly the effect of leptin on oxLDL internalization, the primary cause of foam cell formation. Leptin was found to increase the uptake of moderately oxidized LDLs $\left(\mathrm{oxLDL}_{3}\right)$ by monocytes after 1 and $3 \mathrm{~h}$ of incubation. However, leptin did not seem to affect the uptake of the highly oxidized form of LDLs (oxLDL $\mathrm{L}_{24}$ ) at the time points measured (1, 3 and $5 \mathrm{~h}$, data not shown). This finding is in accordance with a previous study in which CD36 ap- peared to be more active towards mildly oxidized lipoproteins and less active towards fully oxidized lipoproteins [38]. Based on our results, we suggest that increased ox $\mathrm{LDL}_{3}$ uptake by human monocytes is also due to leptin-induced CD36 surface expression. The increase in oxLDL $L_{3}$ uptake induced by leptin was diminished after inhibition of NHE1, PI3K, $\alpha$ and/or $\beta_{\text {I }}$ and $\beta_{\text {II }}$ PKC isoforms and NADPH oxidase, most probably due to lower levels of surface expression of CD36 receptor, as has been shown previously (fig. 4). It is worth mentioning that after $5 \mathrm{~h}$ of treatment with leptin, $\mathrm{oxLDL}_{3}$ uptake declined significantly (data not shown). This could possibly be attributed to apoptotic or necrotic phenomena stemming from the elevated and potentially toxic intracellular concentration of oxLDLs.

Similarly to many cytokines, leptin signaling utilizes the JAK/STAT pathway. The kinase JAK2 associates with $\mathrm{Ob}-\mathrm{Rb}$ and can then activate STAT3, a transcription factor, which in turn mediates the expression of a variety of genes. At the same time, JAK2 can activate PI3K via the activation of insulin receptor substrate-2 [39]. PI3K is known to activate $\mathrm{Ca}^{2+}$-dependent PKCs (such as the $\alpha$ and/or $\beta_{\mathrm{I}}$ and $\beta_{\mathrm{II}}$ isoforms), which then translocate to near the plasma membrane where they can interact with NHE1 [40, 41, 42]. Through another pathway involving the Rho GTPases, PI3K exerts control over the actin cytoskeleton, which in turn is anchored to the plasma membrane through NHE1 and the ezrin, radixin, moesin proteins $[29,43]$. Our results suggest that the pro-atheroscle- 
rotic leptin signal is mediated either through one of the previously mentioned signaling mechanisms initiated from PI3K and reaching NHE1 or through a novel pathway which involves NHE1, PI3K, $\alpha$ and/or $\beta_{\text {I }}$ and $\beta_{\text {II }}$ PKC isoforms and NADPH oxidase-produced reactive oxygen species. The existence of a signaling net regulating the processes we studied instead of just one signaling pathway is another possibility. It is worth noting that, based on our results using the inhibitors DPI and L-NAME, NO synthase does not appear to take part in leptin signaling, at least in terms of the monocyte properties we studied.

The role of the reactive oxygen species produced by NADPH oxidase is difficult to deduce. Our group has recently shown that monocytes from healthy individuals attach to a higher degree to oxidized laminin-1 [44]. As a microenvironment event, this could explain the role of NADPH oxidase in cell adhesion. However, its role in CD36 expression and ox $\mathrm{LDL}_{3}$ uptake requires further research.

In conclusion, we have demonstrated that leptin guides human monocytes in a pro-atherogenic direction. In particular, leptin increases the level of interaction be- tween human monocytes and the extracellular matrix by favoring adhesion to and migration through laminin-1, while at the same time enhancing their ability to internalize moderately oxidized oxLDLs. In summary, NHE1, the actin cytoskeleton, PI3K, certain PKC isoforms and NADPH oxidase appear to be involved in the signaling mechanisms that regulate the aforementioned monocyte properties. However, their exact positions in these signaling mechanisms are difficult to pinpoint. Further research is necessary in order to fully elucidate the mechanism through which leptin promotes monocytic pro-atherogenic properties.

\section{Acknowledgements}

The authors would like to thank Ms. Christina Befani for her excellent technical and secretarial assistance.

This research project was co-financed by the European Social Fund of the European Union (75\%) and the Greek Secretariat for Research and Technology of the Greek Ministry of Development (25\%).

\section{References}

1 Meier U, Gressner AM: Endocrine regulation of energy metabolism: review of pathobiochemical and clinical chemical aspects of leptin, ghrelin, adiponectin and resistin. Clin Chem 2004;50:1511-1525.

-2 Sierra-Honigmann MR, Nath AK, Murakami C, Garcia-Cardena G, Papapetropoulos A, Sessa WC, Madge LA, Schechner JS, Schwabb MB, Polverini PJ, Flores-Riveros JR: Biological action of leptin as an angiogenic factor. Science 1998;281:1683-1686.

- 3 La Cava A, Matarese G: The weight of leptin in immunity. Nat Rev Immunol 2004;4:371379.

4 Beltowski J: Leptin and atherosclerosis. Atherosclerosis 2006;189:47-60.

5 Zarkesh-Esfahani H, Pockley G, Metcalfe RA, Bidlingmaier M, Wu Z, Ajami A, Weetman AP, Strasburger CJ, Ross RJ: High-dose leptin activates human leukocytes via receptor expression on monocytes. J Immunol 2001;167:4593-4599.

6 Cathcart MK: Regulation of superoxide anion production by NADPH oxidase in monocytes/macrophages: contributions to atherosclerosis. Arterioscler Thromb Vasc Biol 2004;24:23-28.

7 Bodary PF, Westrick RJ, Wickenheiser KJ, Shen Y, Eitzman DT: Effect of leptin on arterial thrombosis following vascular injury in mice. JAMA 2002;287:1706-1709.
8 Konstantinides S, Schäfer K, Neels JG, Dellas C, Loskutoff DJ: Inhibition of endogenous leptin protects mice from arterial and venous thrombosis. Arterioscler Thromb Vasc Biol 2004;24:2196-2201.

$\checkmark 9$ Napoleone E, Di Santo A, Amore C, Baccante G, Di Febbo C, Porreca E, De Gaetano G, Donati $M$, Lorenzet $R$ : Leptin induces tissue factor expression in human peripheral blood mononuclear cells: a possible link between obesity and cardiovascular risk? J Thromb Haemost 2007;5:1462-1468.

10 Stocker R, Keaney JF Jr: Role of oxidative modifications in atherosclerosis. Physiol Rev 2004;84:1381-1478.

11 Boisvert WA: Modulation of atherogenesis by chemokines. Trends Cardiovasc Med 2004;14:161-165.

12 Glass CK, Witztum JL: Atherosclerosis: the road ahead. Cell 2001;104:503-516.

13 Quehenberger O: Thematic review series. The immune system and atherogenesis: molecular mechanisms regulating monocyte recruitment in atherosclerosis. J Lipid Res 2005;46:1582-1590.

14 Martin-Romero C, Sanchez-Margalet V: Human leptin activates PI3K and MAPK pathways in human peripheral blood mononuclear cells: possible role of Sam68. Cell Immunol 2001;212:83-91.
15 Dong F, Zhang X, Ren J: Leptin regulates cardiomyocyte contractile function through endothelin-1 receptor-NADPH oxidase pathway. Hypertension 2006;47:222-229.

-16 Seager-Danciger J, Lutz M, Hama S, Cruz D, Castrillo A, Lazaro J, Phillips R, Premack B, Berliner J: Method for large scale isolation, culture and cryopreservation of human monocytes suitable for chemotaxis, cellular adhesion assays, macrophage and dendritic cell differentiation. J Immunol Methods 2004;288:123-134.

17 Verdegaal ME, Zegveld ST, van Furth R: Heat shock protein 65 induces CD62e, CD106 and CD54 on cultured human endothelial cells and increases their adhesiveness for monocytes and granulocytes. J Immunol 1996;157:369-376.

18 Koliakos G, Zolota Z, Paletas K, Kaloyianni M: High glucose concentrations stimulate human monocyte sodium/hydrogen exchanger activity and modulate atherosclerosis-related functions. Pflugers Arch 2004; 449:298-306.

19 Hussein D, Taylor SS: Farnesylation of Cenp$\mathrm{F}$ is required for $\mathrm{G} 2-\mathrm{M}$ progression and degradation after mitosis. J Cell Sci 2002;115: 3403-3414.

20 Stephan ZF, Yurachek EC: Rapid fluorometric assay of LDL receptor activity by DiI-labeled LDL. J Lipid Res 1993;34:325-330. 
-21 Itabe H, Mori M, Fujimoto Y, Higashi Y, Takano T: Minimally modified LDL is an oxidized LDL enriched with oxidized phospatidylcholines. J Biochem 2003;134:459465.

-22 Ross R: Atherosclerosis: an inflammatory disease. N Engl J Med 1999;340:115-126.

-23 Baumgartner M, Patel H, Barber DL: Na(+)/ $\mathrm{H}(+)$ exchanger NHE1 as plasma membrane scaffold in the assembly of signalling complexes. Am J Physiol Cell Physiol 2004;287: C844-C850.

-24 Ley K, Laudanna C, Cybulsky MI, Nourshargh S: Getting to the site of inflammation: the leukocyte adhesion cascade updated. Nat Rev Immunol 2007;7:678-689.

$\checkmark 25$ Curat CA, Miranville A, Sengenes C, Diehl M, Tonus C, Busse R, Bouloumie A: From blood monocytes to adipose tissue-resident macrophages: induction of diapedesis by human mature adipocytes. Diabetes 2004;53: 1285-1292.

-26 Pedraza C, Geberhiwot T, Ingerpuu S, Assefa D, Wondimu Z, Kortesmaa J, Tryggvason K, Virtanen I, Patarroyo M: Monocytic cells synthesize, adhere to, and migrate on laminin-8 $\left(\alpha_{4} \beta_{1} \gamma_{1}\right)$. J Immunol 2000;165:58315838.

-27 Desban N, Lissitzky JC, Rousselle P, Duband JL: $\alpha_{1} \beta_{1}$-integrin engagement to distinct laminin-1 domains orchestrates spreading, migration and survival of neural crest cells through independent signaling pathways. J Cell Sci 2006;119:3206-3218.

28 Raftopoulou M, Hall A: Cell migration: Rho GTPases lead the way. Dev Biol 2004;265: 23-32.
29 Cardone RA, Bagorda A, Bellizzi A, Busco G, Guerra L, Paradiso A, Casavola V, Zaccolo M, Reshkin SJ: Protein kinase A gating of a pseudopodial-located RhoA/ROCK/p38/ NHE1 signal module regulates invasion in breast cancer cell lines. Mol Cell Biol 2005; 16:3117-3127.

30 Stephens L, Ellson C, Hawkins P: Roles of PI3Ks in leukocyte chemotaxis and phagocytosis. Curr Opin Cell Biol 2002;14:203213.

-31 Irani K: Oxidant signaling in vascular cell growth, death, and survival: a review of the roles of reactive oxygen species in smooth muscle and endothelial cell mitogenic and apoptotic signaling. Circ Res 2000;87:179183.

32 Davis KL, Martin E, Turko IV, Murad F: Novel effects of nitric oxide. Annu Rev Pharmacol Toxicol 2001;41:203-236.

33 Gutierrez J, Ballinger SW, Darley-Usmar VM, Landar A: Free radicals, mitochondria and oxidized lipids: the emerging role in signal transduction in vascular cells. Circ Res 2006;99:924-932.

34 Dhaliwal BS, Steinbrecher UP: Scavenger receptors and oxidized low density lipoproteins. Clin Chim Acta 1999;286:191-205.

35 Silverstein RL, Febbraio M: CD36 and ath erosclerosis. Curr Opin Lipidol 2000;11: 483-491.

36 van Berkel TJ, Out R, Hoekstra M, Kuiper J, Biessen E, van Eck M: Scavenger receptors: friend or foe in atherosclerosis? Curr Opin Lipidol 2005;16:525-535.

37 Palanivel R, Eguchi M, Shuralyova I, Coe I, Sweeney G: Distinct effects of short- and long-term leptin treatment on glucose and fatty acid uptake and metabolism in HL-1 cardiomyocytes. Metabolism 2006;55:10671075 .
38 Kunjathoor VV, Febbraio M, Podrez EA, Moore KJ, Andersson L, Koehn S, Rhee JS, Silverstein R, Hoff HF, Freeman MW: Scavenger receptors class A-I/II and CD36 are the principal receptors responsible for the uptake of modified low density lipoprotein leading to lipid loading in macrophages. J Biol Chem 2002;277:49982-49988.

39 Sweeney G: Leptin signalling. Cell Signal 2002;14:655-663

40 Attoub S, Noe V, Pirola L, Bruyneel E, Chastre E, Mareel M, Wymann MP, Gespach C: Leptin promotes invasiveness of kidney and colonic epithelial cells via phosphoinositide 3-kinase-, rho- and rac-dependent signaling pathways. FASEB J 2000;14:2329-2338.

$\checkmark 41$ Li L, Mamputu JC, Wiernsperger N, Renier G: Signaling pathways involved in human vascular smooth muscle cell proliferation and matrix metalloproteinase- 2 expression induced by leptin: inhibitory effect of metformin. Diabetes 2005;54:2227-2234.

42 Maly K, Strese K, Kampfer S, Uebeall F, Baier G, Ghaffari-Tabrizi N, Grunicke HH, Leitges $\mathrm{M}$ : Critical role of protein kinase $\mathrm{C}$ and calcium in growth factor induced activation of the $\mathrm{Na}(+) / \mathrm{H}(+)$ exchanger NHE1. FEBS Lett 2002;521:205-210.

43 Meima ME, Mackley JR, Barber DL: Beyond ion translocation: structural functions of the sodium-hydrogen exchanger isoform-1. Curr Opin Nephrol Hypertens 2007; 16:365372 .

44 Kostidou E, Koliakos G, Alamdari DH, Paletas K, Tsapas A, Kaloyianni M: Enhanced laminin carbonylation by monocytes in diabetes mellitus. Clin Biochem 2007;40:671679. 